J. Dairy Sci. 96:3399-3399

http://dx.doi.org/10.3168/jds.2013-96-5-3399

(c) American Dairy Science Association ${ }^{\circledR}, 2013$.

\title{
Erratum to "A dynamic model to predict fat and protein fluxes and dry matter intake associated with body reserve changes in cattle" (J. Dairy Sci. 96:2448-2463)
}

\section{Luis O. Tedeschi, Danny G. Fox, and Paul J. Kononoff}

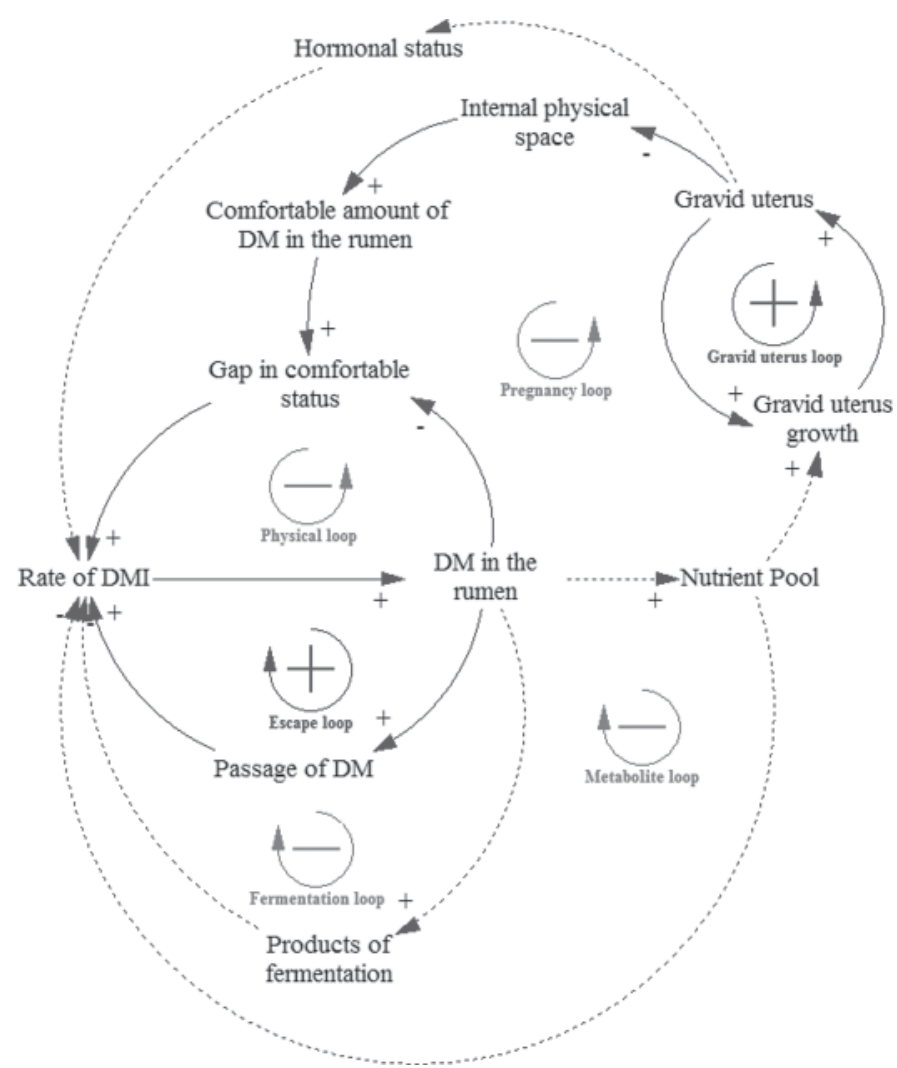

Figure 1. Conceptual representation of long- and short-term feedback loops affecting the dynamics of DMI in a ruminant animal. Selfreinforcing and self-correcting loops are represented by positive and negative signs within the semicircle arrow, respectively. Positive and negative signs near the arrowheads indicate that the effect is positively or negatively related to the cause.
An incorrect version of Figure 1 (page 2450) was included in the paper. The correct version is shown below.

The authors regret the error.

\section{REFERENCES}

Tedeschi, L. O., D. G. Fox, and P. J. Kononoff. 2013. A dynamic model to predict fat and protein fluxes and dry matter intake associated with body reserve changes in cattle. J. Dairy Sci. 96(4):2448-2463. 